\title{
ВЪЗРАСТОВИ ПРОМЕНИ В СКЕЛЕТНИТЕ МУСКУЛИ
}

Вл. Овчаров

\author{
AGING-RELATED CHANGES IN THE SKELETAL MUSCLES \\ V. Ovcharoff
}

Рез юме. Стареенето е свързано с проиеса саркопения, в резултат на което се разрушават мускулните влакна. Това води до загуба на мускулна сила. Причината за това е намаляването на броя на мускулните влакна и особено на белите мускулни влакна. С напредването на възрастта намалява и мускулната регенерация в резултат на смущение в активността на сателитните и имунните клетки. В проиеса на стареенето загиват и много мотоневрони в гръбначния мозък, което води до денервация на мускулните влакна. Намаляването нивото на тестостерона с възрастта води до редукция на мускулната сила. Има достоверни данни, че тренировките за сила и издръжливост забавят и частично възстановяват възрастовите промени в структурата и физиологичните качества на скелетните мускули на човека.

$\mathbf{S}$ u $\mathbf{m} \mathbf{m}$ a ry. The aging is related with the process of sarcopenia, which is related with loss of muscle power and strength. The cause of the reduction of muscle power is the decreasing of the number of the muscle fibers, and especially the type II white fibers. With aging declines the muscle regeneration, while is disturb the activity of satellite and immune cells taking part in muscle regenerative process. With increasing age occurs loss of motoneurons in the spinal cord, which leads to denervation of the muscle fibers. Reduction of the testosterone level plays an important role for the reducing of muscle power. There are supporting data that endurance and strength training can slow and partially some of the age-depending structural and physiological changes in the human skeletal muscles.

○

келетните мускули представляват $35-40 \%$ от телесната маса, като този процент при мъжете е 40-45\%, а при жените - 28-35\%. Има индивиди, при които мускулната маса представлява $45-55 \%$, т.е. половината и повече от телесната маса представляват скелетните мускули. Разпределението на мускулната маса при частите на тялото е както следва: в крайниците се намира $80 \%$ от нея - съответно горни крайници - около $30 \%$ и долни - около 50\%. Скелетните мускули на главата, шията и трупа представляват $20 \%$ от телесната мускулна маса [2].

Скелетните мускули са изградени от мускулни клетки или мускулни влакна. Те са образувани от сливането на едноядрени клетки миобласти. Тези влакна имат стотици и понякога на над хиляда ядра, разположени под клетъчната мембрана, която отвън е покрита от базална ламина. Дължината на мускулните влакна е от микрометри до 30-40 cm. Между клетъчната мембрана на мускулните клетки и базалната ламина се разполагат сателитните или миосателетните клетки. Приема се, че те са стволови клетки, които участват в растежа, хипертрофията и регенерацията на мускулните влакна [1].

По-голямата част от саркоплазмата (цитоплазмата на мускулната клетка) е заета от контрактилни елементи - миофибрили на брой 2500-3000, които заемат 85-90\% от обема на мускулното влакно. Те представляват цилиндрични структури с диаметър 0.5-1 микрометър, простиращи се по цялата дължина на клетката. Всяка миофибрила е изградена от последователно наредени единици наречени саркомери.

Според редица структурни, физиологични и биохимични критерии мускулните влакна се делят на три типа: червени, бели и междинни. Червените или бавните оксидативни влакна или тип I се характеризират с бавни продължителни съкращения и бавно настьпваща умора. Белите или бързите гликолитични мускулни влакна или тип IIb притежават по-бърза сакратимост, но по-бърза уморяемост. Междинните или бързите оксидативно гликолитични мускулни влакна или тип ІІа са преходен тип между червените и белите мускулни влакна.

Основната съставка на скелетните мускули е мускулното влакно или клетка, около която има тънък слой от съединителна тькан - ендомизиум. Те се обединяват в снопчета от 10 до 50. Съединителната тъкан около всяко снопче се нарича перимизиум, а съединтелната тъкан, която покрива целия мускул е наречена епимизиум. В съединителната тъкан на мускулите се намират кръвоносни и лимфни съдове, както и моторни и сетивни нервни влакна. Моторните влакна са аксони на мотоневроните в гръбначния мозък и мозъчния ствол. Тези влакна се свързват с мускулните влакна и се образуват невромускулните синапси.

С напредване на възрастта скелетните мускули тьрпят промени, които се изразяват със загуба на мускулна маса и сила [4]. Тез структурни и функционални промени са известни като саркопения (гр. sarx - месо и penia - загуба). Процесите на саркопения при възрастните индивиди обхващат 4\% до $27 \%$ от изследваните индивиди, като данните са били зависими от пола на изследваните в малка степен. Приема се, че мускулната маса към 75 - 80-годишна възраст намалява с 25\%, което е съществена загуба [5]. След 30-годишна възраст мускулната маса започва да намалява всяка година с $0.5-1 \%$, като този процес сравнително силно се ускорява след 65-годишна възраст. Трябва все пак да се има предвид, че мускулната сила не намалява при всички индивиди, като някои я запазват в съществена степен. Някои възрастни жени запазват сравнително добре силата на мускулите на горните крайници. Намаляването на броя на мускулните влакна започва след 25-годишна възраст и това се отнася особено за белите или бързите мускулни влакна, или тип IIb. В резултат на това се увеличава относително броя на червените или бавните мускулни влакна - тип I и междинните или тип IIa [5]. Това означава загуба на сила и скорост при съкращението на скелетните мускули. Редукцията на обема на мускулите на долните крайници започва в ранната средна възраст и се засилва след 50-годишна възраст. Намаляването на броя на мускулните влакна несъмнено води и до редукция на обема на скелетните мускули. Намаляването на мускулната сила води и до смущение в равновесието на възрастния индивид. Редукцията на мускулната сила е в по-голяма степен, отколкото редукцията на мускулната маса.

Стареенето е процес, който е от най-сыществено значение поради изявеното увеличение на живота в световен мащаб [8]. В края на 2017 г. броят на хората в България на 65+ години е представлявал $21 \%$ от населението в страната, като в сравнени с 2016 г. се е увеличил с $0.3 \%$. Изчислено е, че в световен мащаб до 2050 г. броят на хората над 60-годишна възраст ще се удвои, като достигне до 2 милиарда души, а хората над 80 годишна възраст ще бъдат около 400 милиона [9].

Стареенето е свързано с промени в състава на тялото - намаляване на костната и мускулна маса и изтриването на хрущялните ставни повърхности на големите стави на дол- 
ните крайници и увеличаване на телесната мастна тъкан. Мускулната сила е сериозен показател за същественото ограничение на подвижността на индивида - намаляване скоростта на придвижване, повишен риск от падания и хоспитализации, включително и повишаване на смъртността.

Промените, настьпващи в скелетните мускули, са резултат на два основни фактора - в самите скелетни мускули (вътрешни фактори) и извън тях (външни фактори).

Към вътрешните фактори се включват: намаляване на обема и броя на мускулните влакна и то предимно на бързите или белите мускулни влакна, намаляване на силата на контракция на мускулните влакна, намаляване на протеиновото съдържание на мускулните влакна, намаляване на броя на митохондриите във влакната и смущение във функцията на някои митохондриални ензими, водещо до намаляване на тяхната активност [8], както и до намаляване на митохондриалния дихателен капацитет [7]. По този начин заболявания, свързани с мутации на митохондриалната ДНК, стават много по-тежки с напредване на възрастта. Намалява броят на сателитните клетки, които са стволови клетки [11], участващи в регенерацията на мускулните влакна, като намалява тяхната активност при тези процеси [1]. Появяват се проблеми с отделянето на калций от гладкия ендоплазмен ретикулум, което води до проблеми при съкращението на мускулните влакна. Настъпва процес на инфилтрация на адипоцити между мускулните влакна, както и отлагането на липидни капки в тяхната цитоплазма.

Намаленият брой на сателитните клетки е особено изразено при бързите бели мускулни влакна. Активацията на тези клетки при възрастните индивиди е смутена и те нямат възможност да се намесват активно в регенерацията на увредените мускулни влакна [6]. Има данни за възрастови промени в миофиламентите в мускулните влакна, които вероятно се дължат на промени в миозиновите филаменти. Такива промени водят и до промени в механичните качества на мускулните влакна. Настьпва редукция на еластичността на мускулите, изразяваща се с известна скованост. Този процес вероятно се дължи на формирането на напречни мостове между актиновите и миозинови филаменти в саркомерите. Увеличаването на адипоцитите в мускулите и липидните капки в мускулните влакна води до намаляване на мускулната сила, в резултат на повишената секреция на тумор некрозния фактор алфа. Приема се, че той действа директно на мускулните влакна като уврежда процеса на възбуждане и контракция на тези влакна.

За увреждането на скелетните мускули в процеса на стареенето съществено значение имат редица фактори извън тези мускули. Тук се включват промени в централната нервна система, променена функция на периферната нервна система, промени в структурата и функцията на невромускулните синапси, промените в кръвоснабдяването на мускулите, редица заболявания - сърдечносъдови, тумори, ХОББ (хронична обструктивна белодробна болест), некачествено хранене, намалена физическа активност, хормонални промени, увреждания на гръбначния мозък и други.

Има данни, че при възрастните индивиди около 10\% от алфа-мотоневроните в гръбначния мозък, които инервират скелетните мускули, липсват. Лесно е да се съобрази, че тези мускулни влакна, които са били инервирани от тях, са атрофирали и не могат да се контрахират, т.е. са без функция. Уврежданията на периферните моторни нерви от различни причини имат подобен ефект.

От съществено значение са промените в ендокринната регулация на мускулите. Добре известно е позитивното въздействие на тестостерона върху мускулната маса и сила. Нивото на този хормон от $19 \mathrm{nmol} / \mathrm{L}$ на 30 -год. възраст намалява постепенно на 11 nmol/L при 90-годишните мъже. Знае се, че от четвъртото десетилетие на живота нивото на тестостерона започва да намалява с около $1 \%$ за година. Този процес въздейства върху саркопенията с напредване на възрастта. Загубата на мускулна маса зависи от пола и двигателната активност. Подобно действие имат и други ендокринни фактори. С напредване на възрастта намалява продукцията на анаболните цитокини и IGF1 в скелетните мускули, което обяснява намаляването на синтеза на миофибрилите. Сврьхекспресията на мускулно-специфичния IGF1 намалява мускулната маса с напредване на възрастта. Известно е, че при възрастните индивиди отговорът на мускулите на анаболните и катаболни стимули е по-слабо ефективен в сравнение с млади индивиди. Съществува ефектьт на ,анаболна резистентност“ при скелетните мускули на възрастните индивиди.

Загубата на мускулна маса и сила не е неизбежна с напредване на възрастта. Приема се, че тези загуби могат да се минимизират с тренировките. Тренировките се разделят обикновено на тренировки за издръжливост и тренировки за сила. Има данни, че тренировките за издръжливост повишават аеробния капацитет на мускулите, а силовите тренировки подобряват възможността на централната нервна система да подкрепи и възстанови мускулите, да повиши мускулната маса и сила и да подкрепи регенеративния процес при увредените мускулни клетки, а също и да предотврати смущението в мускулния метаболизъм. Доказано е, че физическата активност е препоръчителна за превенция на възрастовото въздействие върху скелетните мускули. Адаптацията на скелетните мускули към тренировъчния процес зависи от интензивността, вида упражнения и тяхната продължителност. Подходящо избрани упражнения могат да забавят, променят и даже частично да подобрят някои физиологични промени, включително саркопенията, които се осъществяват в скелетната мускулатура.

Адаптацията на мускулите на възрастни хора се осъществява като се използват един-два вида тренировки - прогресивна тренировка със съпротивление (тежест) и високо интензивна тренировка.

Прогресивната тренировка със съпротивление може да се структурира по следния начин:

\begin{tabular}{|c|c|c|}
\hline 4-8 седмици & $\begin{array}{c}3 \text { сета по 8-10 } \\
\text { повторения }\end{array}$ & $\begin{array}{c}\text { 60-75\% от максимума, който } \\
\text { може да се повдигне }\end{array}$ \\
\hline 9-12 седмици & $\begin{array}{c}3 \text { сета по 4-6 } \\
\text { повторения }\end{array}$ & $\begin{array}{c}75-90 \% \text { от максимума, който } \\
\text { може да се повдигне }\end{array}$ \\
\hline
\end{tabular}

Високо интензивната тренировка се изпълнява по следния начин:

\begin{tabular}{|c|c|c|}
\hline $\begin{array}{c}3 \text { пъти сед- } \\
\text { мично }\end{array}$ & $\begin{array}{c}2-6 \text { сета по } 8 \\
\text { повторения }\end{array}$ & $\begin{array}{c}\text { 80\% от максимума, който } \\
\text { може да се повдигне }\end{array}$ \\
\hline
\end{tabular}

Друга възможност е следната:

\begin{tabular}{|c|c|c|}
\hline $\begin{array}{c}3 \text { пъти сед- } \\
\text { мично }\end{array}$ & $\begin{array}{c}3 \text { сета по } 8 \\
\text { повторения }\end{array}$ & $\begin{array}{c}80 \% \text { от максимума, който } \\
\text { може да се повдигне }\end{array}$ \\
\hline
\end{tabular}

Съществува едно погрешно мнение, че възрастните хора трябва да „тренират леко“. Разбира се в началото на този процес трябва да се използват леки тежести. Разбира се трябва да се има предвид съответните болести, които има индивидът - диабет, сърдечни заболявания, нарушения в равновесието и други.

Тренировъчният процес може да ограничи и намали процесите на саркопения при възрастните хора. Редовната силова тренировка при индивиди във възрастовата група 60-97 години е довела до повишаване силата на скелетните мускули. Добри резултати са постигнати при ходене или бавно бягане по 45 минути на ден, 3 пъти през седмицата, което е довело до увеличаване на червените бавни мускулни влакна при жени и мъже. 
Трябва да се има предвид, че мускулите на възрастни индивиди при тренировъчния процес се увреждат по-лесно понякога в сравнение на младите индивиди. Нуждата от протеини в храната или добавки при възрастните е по-изразена, отколкото при младите хора. Не може да се подържа добра мускулна маса и сила без необходимото ниво протеини.

Хранителните навици имат съществено значение за капацитета на скелетните мускули да регенерират при процесите на саркопения [3]. Затлъстяването също така намалява възможностите за регенерация на мускулните влакна при възрастните хора. Приемането на левцин като хранителна добавка води до увеличаване размерите на мускулните влакна и ограничава намаляването на мускулната функция. Протеините на рибеното или моруновото масло имат също положителен ефект като те са богати на глицин, лизин, аргинин и таурин. Полифенолите, включително тези от зеления чай, стимулират регенерацията на мускулните влакна. Подобно действие има витамин $\mathrm{D}_{3}$, който има ниско ниво в организма при възрастни индивиди. Неговото прилагане повишава нивото на регенерацията на мускулните влакна. Подходящата храна е добър и сигурен начин да се засили регенерацията на мускулите при възрастните хора.

Има изследвания, при които е прилагана тестостеронова терапия при възрастни индивиди, при което е наблюдавано запазване обема на мускулите и потискане на саркопенията. Допуска се, че заместителната терапия с тестостерон и тренировка ще подобри структурата и силата на скелетните мускули [10]. В тази насока са необходими и допълнителни изследвания.

Добре известна е мечтата за „вечната младост“, за желания еликсир, който ще ни върне младостта, ,фонтанът на младостта“, който ще ни подмлади. Настьпването на старостта е неумолимо, а често е съпроводено с болести, които допълнително усложняват ситуацията и в никакъв случай не трябва да се забравя начина на живот. Несъмнено опитите да се забавят естествените процеси на стареене има несъществен ефект. Хроничните съпьтстващи болести би трябвало да се държат под някакъв възможен контрол. Начинът на живот е донякъде зависим от съответния индивид, но е в за- висимост от финансови възможности и редица други житейски фактори. Поддържането на мускулната сила и издръжливост, структурата на костите е във възможностите на всеки от нас. Редовната физическа активност е в състояние да осъществи протективен ефект върху възрастовите промени в мускулите и инсулиновата резистентност. Изявената физическа неактивност и заседнал начин на живот могат да се сравнят с ефекта от тютюнопушенето. Редовната физическа активност е от съществено значение не само за двигателната система, но и за превенцията на редица хронични заболявания, като сърдечносъдови, метаболитни, дихателни, имунни и неврологични заболявания.

\section{Библиография}

1. Вл. Овчаров, Цв. Такева. Цитология, обща хистология и обща ембриология, Медицинско издателство АРСО, София, осмо преработено издание - 2017.

2. Вл. Овчаров, В. Ванков. Анатомия на човека (Седмо издание), Медицинско издателство АРСО, четиринадесето издание София 2019.

3. C. Domingues-Faria, M.-P. Vasson, N. Goncalves-Mendes, Y.Boirie, S. Walrand. Skeletal muscle regeneration and impact of aging and nutrition. https://doi.org/10.1016/j.arr.2015.12.004Get rights and content

4. D. T. Kirkendall, W.E. Garrett Jr. The effects of aging and training on skeleyal muscle. Am. J. Sports Med. 26 (4), 598 - 602, 1998.

5. F. Demontis, R. Piccirillo, A.L. Goldberg, N. Perimon. Mechanisms of skeletal muscle aging: insights from Drosophila and mammalian models. Desease Models \& Mechanisms 2013 6: 1339-1352; doi: 10.1242/dmm. 012559

6. F. S. Tedesco, A. Dellavalle, J.Diaz-Manera, G. Messina, G. Cossu. J. Clin. Invest, 120 (1), $11-19,2010$.

7. G. D. Cartee, R.T. Hepp;e, M.M. Bamman, J.R. Zierath. Exercise Promotes Healthy Aging of Skeletal Muscle. Cell Metab. 23 (6), $1034-1047,2016$.

8. G. N. Williams, M.J. Higgins, M.D. Lewek. Aging Skeletal Muscle: Physiological Changes and the Effects of Training. Physical Therapy, Volume 82, Issue 1, 62-68, 2002.

9. N. Miljkovic, J.-Y. Lim, I. Miljkovic, W.R. Frontera. Aging of Skeletal Muscle Fibers. Ann. Rechabil. Med. 39 (2), 155 - 162, 2015.

10. R. A. Atkinson, U. Srinivas-Shankar, S.A. Roberts, M.J. Connolly, J.E. Adams, J.A. Oldham, F.C.W.Wu, O.R. Seynnes, C.E.H. Stewart, C.N. Maganaris. Effects of Testosterone on Skeletal Muscle Architecture in Intermediate-Frail and Frail Elderly Men. J. Gerontology, Series A, Volume 65A, Issue 11, $1215-1219,2010$.

11. S. Manolov, W. Ovtscharoff: Ultrastructural Changes in the Denervated Muscle of Rat. Z. mikrosk.-anat. Forsch. 88, 726 - 744 (1974).

$$
* *
$$

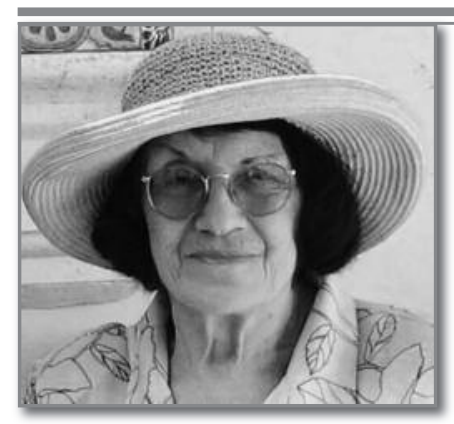

Д-р Лиляна Йорданова Бурилкова (20.04.1925 г. 19.02.2019 г.) е родена в гр. Виена, Австрия. Завършва гимназиално образование в немско класическо девическо училище „Санкта Мария " (1943). Висше медицинско образование завършва във ВМИ София (1950). След дипломирането работи като завеждащ отдел "Хигиена на храненето" в окръжната санитарно-противоепидемична станция в Бургас. През 1958 г. с конкурс постъпва на работа в катедра „Социална хигиена и история на медицината“ към ИСУЛ. Има призната специалност по Социална хигиена (1967). Д-р Л. Бурилкова става един от инициаторите при учредяването на Републиканското научно дружество по история на медицината. От 1978 г. до пенсионирането си през 1981 г. работи като редактор на списание "Здраве". Има над 50 научни публикации и участва в много международни конгреси и конференции. След пенсионирането си сътрудничи на акад. Ташо Ташев като административен секретар и преводач в работата му като председател (1973 -1990) на Межународната медицинска асоциация за изучаване условията на живота и здравето (АМИЕВ). На вниманието в тази авторитетна международна организация стоят актуални теми като: замърсяване на околната среда от физически и и химически фактори, трудова медицина, транспортни злополуки, хранене и здраве, токсикомании със социално значение, хуманизма и медицинската отговорност, рентабилността в службите по обществено здраве. По това време се създават и разширяват ползотворните връзки между АМИЕВ и Балканския медицински съюз. Д-р Бурилкова става член на Редколегията на списание „Социална медицина“ от съ3даването му (1993). Тя всеотдайно сътрудничи в издаването му в продължение на две десетилетия. Неоценима е дейността ѝ с владеенето на важни за медицината чужди езици немски, английски и френски. Тя умело превежда и реферира както актуални материали от Световната здравна организация, така и статии от водещите чуждестранни медицински списания. Сърдечно трябва да благодарим на д-р Лиляна Бурилкова за дългогодишната и прецизна работа. Поклон пред светлата ѝ памет!

Почивай в мир! 